\title{
EFFECT OF MINDFULLNESS MEDITATION ON STRESS LEVEL AND COPING MECHANISM IN CANCER PATIENTS
}

\author{
Yesiana Dwi Wahyu Werdani \\ Faculty of Nursing, Widya Mandala Catholic University \\ Surabaya
}

\begin{abstract}
ABSTRAK
Pasien kanker memiliki kecenderungan untuk mengalami gangguan mental, karena perubahan fisik yang ditimbulkan membuat pasien frustasi dan putus asa, yang berdampak pada munculnya anxietas, depresi, isolasi sosial. Tujuan penelitian ini adalah menganalisis pengaruh mindfullness meditation terhadap tingkat stres dan mekanisme coping pada pasien kanker. Penelitian ini adalah penelitian pra eksperimen dengan pendekatan one group pre-test post-test design. Sampel terdiri dari 32 pasien kanker dengan kesadaran composmentis di Yayasan Kanker Indonesia Cabang Jawa Timur, yang diambil dengan total sampling. Instrumen kuesioner adalah Perceived Stress Scale dan Coping Strategies Inventory. Uji statistik menggunakan Wilcoxon Sign Rank Test dan Paired T-test $P<0.05$. Hasil menunjukkan bahwa pengaruh mindfulness meditation terhadap tingkat stres $p=0.001$, terhadap mekanisme coping adaptive $p=0.001$ dan maldaptif $p=0.003$. Sebagai simpulan, Mindfulness Meditation menyebabkan responden dapat berkonsentrasi dan memusatkan perhatian pada dirinya, dan juga dapat memperkuat daerah otak pada pusat perhatian dan fungsi eksekutif, interoception dan fleksibilitas mental. (FMI 2017;53:33-40)
\end{abstract}

Keywords: Mindfulness Meditation, tingkat stres, mekanisme coping

\begin{abstract}
Cancer patients have a tendency to experience mental disorders, because the physical changes cause frustration and despair. It impacts on anxiety, depression, and social isolation. The purpose of this study was to analyze the influence of mindfullness meditation to stress levels and coping mechanisms in cancer patients. This study used pre experimental approach with one group pre-test post-test design. Samples were 32 cancer patients with composmentis condition in Indonesian Cancer Foundation East Java Branch, taken by total sampling. The instrument was Perceived Stress Scale and Coping Strategies Inventory. Statistics was verified with Wilcoxon Sign Rank Test and Paired T-test $P<0.05$. Results showed the effect of Mindfulness Meditation on the level of stress $p$ $=0.001$, the adaptive of coping mechanisms $p=0.001$ and maldaptive $p=0.003$. In conclusion, Mindfulness meditation can cause the respondent to concentrate and focus on themselves, and also strengthen brain regions at the center of attention and executive function, interoception and mental flexibility. (FMI 2017;53:33-40)
\end{abstract}

Keywords: Mindfulness Meditation, stress levels, coping mechanisms

Correspondence: Yesiana Dwi Wahyu Werdani, Jl. Raya Kalisari Selatan No. 1, Pakuwon City, Surabaya, Indonesia. Phone: +6285857967430. Email. e-mail: ywerdani@yahoo.com

\section{INTRODUCTION}

Physical and psychological changes as a result of cancer will be a stressor for the patient. The emergence of a variety of new complaints or diseases in cancer patients often make patients become frustrated and hopeless, which ultimately gives a negative impact of the emergence of symptoms of mental disorders such as anxiety, depression, social isolation and even other mental disorders are more severe degrees. Singer, Munshi \& Brahler (2009) mentioned that of 1448 cancer patients under study, 456 were diagnosed with a mental disorder. Based on the results of the preliminary survey in April 2016 there were 26 cancer patients living at the Indonesian Cancer Foundation (YKI) East Java Branch, with the highest prevalence being cervical cancer. These patients have never been given psychotherapy in the form of mindfulness meditation.

Patients suffering from illness have some psychological characteristics of anxiety, loss of self-control, loss of hope, loss of body integrity, helplessness, depression, dependence, fear of neglect, fear of death, loss of selfidentity and special meaning of the disease itself for the patient (Sollner 2006).

One of the palliative treatments that can be given to cancer patients is Mindfullness Meditation which is an activity given to patients with terminal illness that involves the element of awareness, attention and memory to be able to see and accept the reality of life better. Carlson \& Garland (2005), who studied outpatient 
cancer patients, received a decrease in stress, mood disorders and fatigue with $\mathrm{p}<.001$. This study examines the effect of mindfullness meditation on stress levels and coping mechanisms in cancer patients. The purpose of this study determine the influence of mindfullness meditation on stress levels and coping mechanisms in cancer patients.

\section{MATERIALS AND METHODS}

This study used pre experimental design with one group pre-test post-test design. The sample was cancer patient with composmentis consciousness at YKI Branch of East Java which amounted to 32 people, taken using total sampling technique.

This study uses two types of instruments, a stress level questionnaire (PSS), and a coping mechanism inventory (CSI) coping questionnaire. After signing the informed consent, respondents were given pre test in the form of filling out the stress level questionnaire and coping mechanism. All respondents were treated in the form of mindfullness meditation $2 \mathrm{x}$ a week with 45 minutes duration in each meeting and conducted for 4 weeks. After the treatment period is completed, post test is done by giving more questionnaire about stress level and coping mechanism. After the data collected, the researcher performs coding, scoring and tabulation.

\section{RESULTS}

The majority of respondents $(40.6 \%)$ aged 51-60 years and dominated by women $(87.5 \%)$. Concerning the marital status of the majority of respondents (65.6\%) has been married and the highest educational background is SMA 50\%, while some $62.6 \%$ of respondents are housewives. The majority of respondents (75\%) have no family history of cancer. Most of the respondents $(75 \%)$ had cancer for $<1$ year with the highest stage $(46.9 \%)$ was stage II. The majority of respondents $(37.5 \%)$ underwent radiation therapy. During the treatment most respondents $(84.4 \%)$ were accompanied by the nuclear family.

Table 1. General data of respondents at Yayasan Kanker Indonesia Branch East Java, June 2016

\begin{tabular}{|c|c|c|c|}
\hline General data & Categories & $\begin{array}{c}\begin{array}{c}\text { Frequency } \\
\text { (persons) }\end{array} \\
\end{array}$ & $\begin{array}{l}\text { Percentage } \\
(\%)\end{array}$ \\
\hline \multirow[t]{5}{*}{ Age } & $\leq 30$ years & 3 & 9.4 \\
\hline & $\overline{3} 0-40$ years & 1 & 3.1 \\
\hline & $41-50$ years & 10 & 31.3 \\
\hline & $51-60$ years & 13 & 40.6 \\
\hline & $>60$ years & 5 & 15.6 \\
\hline \multirow[t]{2}{*}{ Sex } & Female & 28 & 87.5 \\
\hline & Male & 4 & 12.5 \\
\hline \multirow[t]{4}{*}{ Marriage status } & Unmarried & 2 & 6.3 \\
\hline & Married & 21 & 65.6 \\
\hline & Widow & 7 & 21.8 \\
\hline & Widower & 2 & 6.3 \\
\hline \multirow[t]{2}{*}{ Family cancer history } & Present & 8 & 25 \\
\hline & Absent & 24 & 75 \\
\hline \multirow{4}{*}{$\begin{array}{l}\text { Time of diagnosed with } \\
\text { cancer }\end{array}$} & $<1$ years & 24 & 75 \\
\hline & $1-<2$ years & 4 & 12.5 \\
\hline & $2-<3$ years & 3 & 9.4 \\
\hline & $>3$ years & 1 & 3.1 \\
\hline \multirow[t]{3}{*}{ Cancer stage } & II & 15 & 46.9 \\
\hline & III & 13 & 40.6 \\
\hline & IV & 4 & 12.5 \\
\hline \multirow[t]{4}{*}{ Undergoing therapy } & Kemoterapi & 11 & 34.4 \\
\hline & Radiasi & 12 & 37.5 \\
\hline & Kemoterapi + radiasi & 6 & 18.7 \\
\hline & Operasi + Kemoterapi & 3 & 9.4 \\
\hline \multirow[t]{2}{*}{ Companion during therapy } & Keluarga inti & 27 & 84.4 \\
\hline & Sendiri & 5 & 15.6 \\
\hline
\end{tabular}




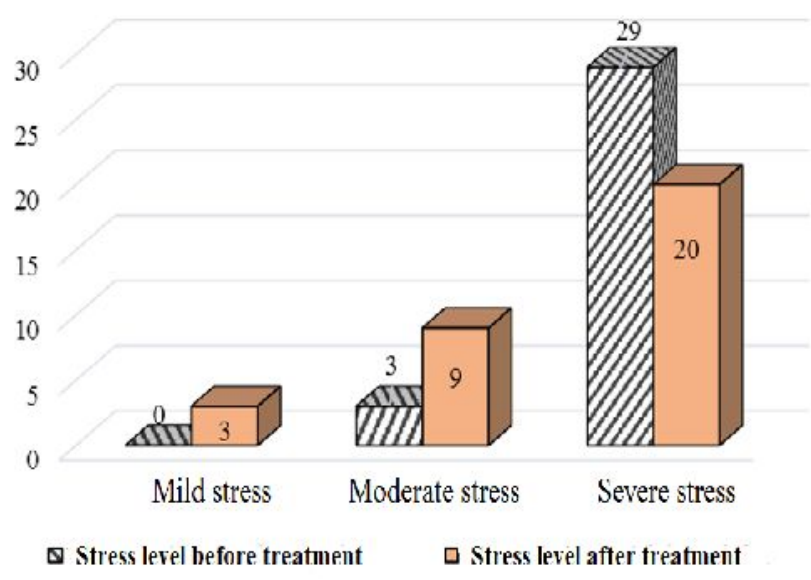

Fig. 1. Stress level of respondents before and after Mindfullness Meditation at Cancer Foundation Indonesia Branch East Java, June 2016

Prior to treatment, the majority of respondents $(90.6 \%)$ were at a serious stress level and only 3 people $(9.4 \%)$ had moderate stress, not even a single person at a mild stress level. However, after the treatment of mindfullness meditation for 4 weeks, there was a change of condition, the majority of stress level remained at the level of severe stress, but the number had started to decrease as many as 20 people $(62.5 \%)$, while the number of respondents with stress level was increased to 9
(28.1\%), and there were also 3 respondents $(9.4 \%)$ who were at a mild stress level.

Table 2. Coping mechanism of respondents before and after Mindfullness Meditation at Cancer Foundation Indonesia Branch East Java, June 2016

\begin{tabular}{lcc}
\hline \multicolumn{1}{c}{ Measured factor } & $\begin{array}{c}\text { Pre } \\
\text { Mean } \pm \text { SD }\end{array}$ & $\begin{array}{c}\text { Post } \\
\text { Mean } \pm \text { SD }\end{array}$ \\
\hline Adaptive coping mechanism score & $2.36 \pm 0.18$ & $2.58 \pm 0.38$ \\
\hline Maladaptive coping mechanism score & $3.28 \pm 0.20$ & $2.96 \pm 0.55$ \\
\hline
\end{tabular}

In adaptive coping mechanism before giving mindfullness meditation, the mean score obtained was 2.36, while after treatment there was an increase of mean score to 2.58 . In the maladaptive coping mechanism, before giving the mindfullness meditation the average score obtained is 3.28 , but after being given the treatment decreased the average score to 2.96 .

The treatment of mindfullness meditation had a significant influence on stress level of respondents, with significance value of 0.001 (Table 3). Mindfullness Meditation also has a significant influence on adaptive coping mechanism with significance value of 0.001 , whereas in maladaptive coping mechanism the significance value is 0.003 .

Table 3. Effect of Mindfullness Meditation on stress level, Indonesian Cancer Foundation of East Java Branch, June 2016

\begin{tabular}{|c|c|c|c|c|}
\hline Measured factor & $\begin{array}{l}\text { Mean } \\
\text { Negative } \\
\text { rank }\end{array}$ & $\begin{array}{l}\text { Mean } \\
\text { Postive } \\
\text { Rank }\end{array}$ & $\mathrm{Z}$ & $\begin{array}{l}\text { Sig. (2- } \\
\text { tailed) }\end{array}$ \\
\hline $\begin{array}{l}\text { Stress level before Mindfulness } \\
\text { Meditation - Stress level after } \\
\text { Mindfulness Meditation }\end{array}$ & .00 & 6.50 & $3.464^{\mathrm{a}}$ & 001 \\
\hline
\end{tabular}

Table 4. Effect of Mindfullness Meditation on Coping Mechanism, Cancer Foundation of Indonesia Branch of East Java, June 2016

\begin{tabular}{|c|c|c|c|c|}
\hline Measured factor & Mean & SD & $\mathrm{T}$ & Sig. (2-tailed) \\
\hline $\begin{array}{l}\text { Adaptive coping mechanism before } \\
\text { Mindfulness Meditation - Adaptive } \\
\text { coping mechanism after Mindfulness } \\
\text { Meditation }\end{array}$ & -.22000 & .34879 & -3.568 & .001 \\
\hline $\begin{array}{l}\text { Adaptive coping mechanism before } \\
\text { Mindfulness Meditation - Adaptive } \\
\text { coping mechanism after Mindfulness } \\
\text { Meditation }\end{array}$ & .31438 & .55075 & 3.229 & .003 \\
\hline
\end{tabular}




\section{DISCUSSION}

In this study calculation with Wilcoxon Sign Rank Test on stress level variable obtained $\mathrm{p}=0.001$, and calculation with Paired T-test on variable coping mechanism adative $\mathrm{p}=0.001$ and maladaptive coping mechanism $\mathrm{p}=0.003$. This implies that there is a significant effect on the provision of mindfulness meditation on stress levels and coping mechanisms. This meaningful effect occurs because when practicing mindfulness meditation, the respondent can really concentrate and concentrate on her, because the room and the facility of holding the mindfulness meditation is very wide with quiet situation, and the relaxation music accompaniment can really make the patient able to relax The whole mind, and consciously able to incorporate positive thoughts that can change their ways of thinking and their outlook for the better.

A person who has a positive mind will experience a state of relaxation. According Nurdin (2010), at the time of dopamine relaxation will be bound to dopamine D2 Receptor on Nukelus Akumben. This will lead to feelings of comfort, decreased levels of adrenaline, noradrenaline and glucocorticoids, so that all the functions of body homeostasis fall back to the basal level.

According to Davis \& Hayes (2012), mindfulness meditation is useful for lowering stress, improving memory and ability to focus attention, decreasing emo-tional reactivity, increasing cognitive flexibility, rela-tionship satisfaction, and reducing fear/anxiety.

Ott, Norris \& Wu (2006) did a review on nine articles. The results stated that after being given mindfulness intervention, breast cancer patients and prostate cancer who were undergoing outpatient treatment, improved psychological function, reduced stress symptoms, and increased individual coping. Another supporting study was also conducted by Chandwani (2012), where a 6 week program of mindfulness therapy for breast cancer patients was found to reduce anxiety, depression, and fear of disease recurrence and better perception of physical function. Similarly Goyal et.al (2014), who reviewed 47 studies with 3515 respondents, stated that mindfulness meditation programs improved anxiety, depression, pain and reduced stress and mental health.

The link between psychological intervention and stress reduction in detail has been revealed by Lutgendorf \& Costanzo (2003). They illustrate the relationship between psychosocial processes, biological factors, and health behaviors that may affect susceptibility to disease, disease onset, disease progres- siveness, recurrence, recovery and survival of a person's quality of life. Intervention in the form of psychotherapy can modulate the effects of psychosocial processes and health behaviors on neuroendocrine and immune mechanisms that result in better health status.

In Figure 2, Lutgendorf \& Costanzo (2003) describes in detail that Box A psychosocial process consists of psychological and social factors, primarily involving the interpretation and response of a person to stress, including personality variables (such as optimistic personality, hostility, negative influence), Mental health variables, mood (mood), coping, social support, spiritual, and sense of meaningfulness. While Box. C is a health behavior consisting of the use of narcotics and alcohol, smoking, sleep, nutrition, exercise, medication adherence, physical examination, risk screenings, and risky sexual behavior. Health psychological interventions can be given to alter the psychosocial processes in Box A, such as interventions to reduce depression, and improve coping or improve health behavior in Box $\mathrm{C}$, such as quitting smoking. The goal of the intervention is to provide a more positive effect on neuroendocrine, immune factors, and also to slow the progression of disease and recurrence. Interventions of health psychology that can be done include Cognitive Behavioral Stress Management (CBSM), relaxation, hypnosis, mindufllness meditation, emotional disclosure, adherence-based intervention, sleep hygiene, exercise, social support groups, psychotherapy, image-ry, distraction, behavioral pain management, yoga massage, biofeedback, drug/alcohol prevention/rehabilitation, and behavioral conditioning.

The above intervention can be used based on a specific disease or condition. In box $\mathrm{F}$ shows the choice of mechanisms involved in a two-way interaction between neuroendocrine and immune axes that mediate the relationship between biobehavioral factors in A-D boxes and disease outcomes in the G-J box. If through the neuroendocrine path then involved are HPA (Hypothalamic Pituitary Adrenocortical Axis), SAM (Sympathoadrenomedullary Axis), HPG (hypophyseal pituitary gonadal axis), OT (oxytocin), DA (Dopamine), 5HT (seratonin), and GH (growth hormone ). The immune mechanisms involved are NKCC (Natural killer cell cytotoxicity), CTLs (cytotoxic lymphocytes), M (macrophage), IL-1 (interleukin 1), IL-6 (interleukin 6), $\mathrm{TGFb}$ (transforming growth factor beta), Ab (antibody), and VEGF (vascular endothelial growth factor). 


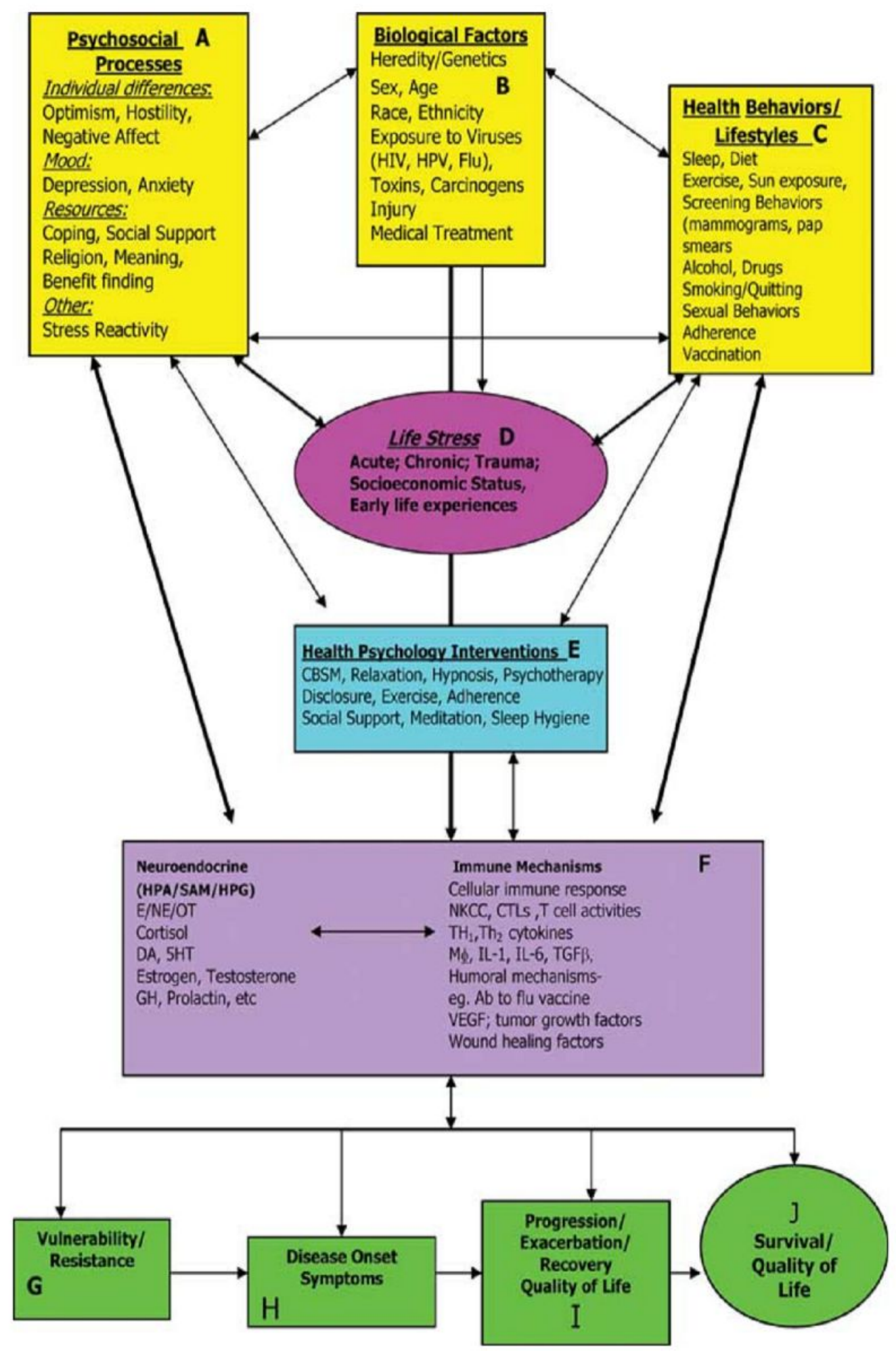

Figure 2. The Biopsychosocial Model (Lutgendorf \& Costanzo (2003) 
The HPA Axis response to mindfullness meditation therapy (MMT) has been studied by John, Verma \& Khanna (2011) who studied salivary cortisol in respondents who administered MMT exercises. The results showed that salivary cortisol in respondents undergoing MMT exercise decreased significantly from baseline values ??of 1.33 to 0.66 on day 29; $(\mathrm{F}=834.6 \mathrm{p}$ $<0.001)$.

Mindfulness meditation is one of the modalities of therapy that has a way of working that can affect the brain. According to Farb, Segal \& Mayberg (2007) the brain has the ability to change its structure and function. Mindfullness meditation can strengthen brain areas associated with the focus and executive function, interoception (ability to feel internal body sensations), and mental flexibility, and proven to also attenuate activity in the amygdala. The dorsal medial prefrontal, cortex and anterior cingulate cortex regions in both hemispheres are activated during mindfullness meditation. Cingulate cortex plays a major role in the fusion of attention, motivation, and motor control (Sridharan, Levitin \& Menon 2008).

This is supported by Holzel et al (2011), which examined 17 individuals who were given Mindfullness Based on Stress Reduction therapy for 8 weeks. The results suggest that increased concentrations occur in gray matter in the left hippocampus. All parts of the brain were analyzed and identified an increase in the posterior cingulate cortex, and temporo-parietal junction, as well as on the cerebellum. This increased activity in the brain causes memory process improvement and emotional regulation. The same thing was also found by Taren et al (2015), which examined 35 respondents with moderate to severe stress levels. Prior to the intervention all respondents performed neuroimaging examinations, indicating the occurrence of bilateral enlargement of the resting state Functional Connectivity (rsFC) in the anterior amberglut subgenual cingulate cortex ( $\mathrm{sgACC}$ ), which is an area that serves to coordinate the processing of stress. After intensive Mindfullness Based-Stress Reduction for 3 days, there was a decrease in resting state Functional Connectivity (rsFC) in the subgenual anterior amberdene cingulate cortex (sgACC). This means the stress processing response goes well.

The decrease of stress level in this study caused the respondents to improve also in managing the coping mechanism. This is evidenced by an increase in scores on adaptive coping mechanisms from 2.36 to 2.58 and decreased maladaptive coping mechanism from 3.28 to 2.96 .
According to Ahyar (2010), the way individuals deal with stressful situations is determined by individual resource factors that include physical health, positive beliefs or outlook, problem-solving skills, social skills, social support, employment, age, gender and education. In this study there are four factors that can influence the increase of score on coping mechanism to be adaptive. First, the belief factor or the positive outlook. When giving mindfulness meditation treatment, patients are trained to calm down and focus their attention on themselves, and at the same time be given positive sentences that reinforce and assure them that things are not as bad as imagined and deserve to be grateful. Second, problem-solving skills. In mindfulness meditation researchers also include positive sentences about what should be done by a person who is suffering from pain, so that pain can be felt with joy.

The third factor is social skills. At the moment of mindfulness meditation at the end of the session the researcher gives opportunity to all participants to give smile and greeting to the friends who are beside, front and back. This turned out to be a good response, because after giving a smile, they can communicate well with other participants. The fourth factor is social support. At the time of mindfulness meditation, most of the respondents were followed by the supervisors who monitor from the back, the purpose of this counseling participation is to monitor the patient because remembering the post-radiation/chemotherapy patients who still allow is residual complaints. During the process of mindfulness meditation therapy, the patient's companions only observed it, but the observations also changed their mindset in providing assistance to patients. Based on the results of the interview with the counselors, they stated that before knowing about mindfulness meditation, they act casual when the patient pours out his sad feelings, but after seeing the mindfulness of meditation, they always give positive response to the patient's heart.

Garland, Gaylord \& Park (2009) suggest that mindfulness therapy can influence an individual's positive judgment that leads to the process of adaptive coping mechanisms. The emergence of positive thinking in post-mindfulness meditation patients indirectly also reduce the level of stress, so actually between stress and coping mechanism has a reciprocal relationship. When a person has a low stress level then the coping mechanism gets better, and vice versa. This will further improve the quality of his life and be more able to accept themselves as they are.

Mousavi, Esmaeili \& Saless (2015) studied 15 cancer patients who were given intervention in the form of positive thinking training for 8 sessions for 3 weeks. 
Results showed that respondents had better quality of life than control group with $\mathrm{p} 0.00$. The same thing was also expressed by Witek-Janusek et al. (2008) who examined immunologic responses to stress in women newly diagnosed with breast cancer. Respondents were given Meditation Based Stress Reduction therapy and the results obtained showed a significant improvement in the quality of life and immunological effects on the respondents.

According to Malinoswki (2013), the main structural model of mindfulness meditation is the motivating factor that determines what and how an individual engages in mindfullness meditation activities. Regular involvement in mindfulness meditation will be able to develop and purify mental core processes that include enhancing the function of attention, the process of emotional regulation and cognition. Improvements in this core process result in a more balanced and more positive mental attitude in terms of physical and mental well-being, as well as the quality of behavior. Each component in this model is assumed to have a causal relationship. Combined all these factors can lead to an optimistic attitude. This is similar to a study by Shaheen et al (2014), which examined 80 female patients with breast cancer by measuring their level of optimism against stress levels. The results obtained are women with high optimism experience can reduce the level of stress after positive diagnosed breast cancer, compared with respondents who have low optimism. According to Brydon et al (2009) someone who has an optimistic attitude will reduce levels of interleukin 6 which plays an important role to increase antibodies and protective to health.

\section{CONCLUSION}

Mindfullness meditation performed regularly can help lower stress levels and improve individual responses in adapting to problems adaptively and decrease maladaptive responses in patients with cancer. Mindfullness meditation can improve a positive mindset, so that the process of individual self-acceptance becomes better. Thus the response of the body through the mechanism of HPA-Axis can work well by lowering the levels of cortisol and interleukin 6, which in turn has an impact on improving the quality of life, so that cancer patients can maintain their health condition optimally.

\section{REFERENCES}

Ahyar, W 2010, Konsep Diri dan Mekanisme Coping, Jakarta, Rineka Cipta.
Brydon, L., Walker, C., Wawrzyniak, A.J., Chart, H., \& Steptoe, A 2009, Dispositional Optimism and StressInduced Changes in Immunity and Negative Mood. Brain, Behavior, and Immunity, Vol. 23, No. 6, pp. 810-816.

Carlon, L \& Garland, S 2005, Impact of mindfulnessbased stress reduction (MBSR) on sleep, mood, stress and fatigue symptoms in cancer outpatients, International Journal of Behavioural Medicine, Vol. 12, Issue 4, pp. 278-285.

Chandwani, K., Ryan, J., Peppone, L., Janelsins, M., et.al 2012, Cancer-Related Stress and Complementary and Alternative Medicine: A Review. Journal of Evidence-Based Complementary and Alternative Medicine. Vol. 2012.

Davis, D \& Hayes, J 2012, What Are The Benefits of Mindfulness. American Psychological Association, Vol. 43, No. 7.

Farb, Segal, Z., Mayberg H, et al 2007, Attending to The Present: Mindfulness Meditation Reveals Distinct Neural Modes Of Self-Reference, Social Cognitif Affect Neuroscience Vol. 2, no.4, 313-322.

Garland, E., Gaylord, S., Park, J 2009, The Role of Mindfullness in Positive Appraisal. Journal of Pubmed Central, Vol. 5, no. 1. pp 37-44.

Goyal, M. Singh, S., Sibinga, E, et al 2014. Meditation Programs for Psychological Stress and Well-being: a Systematic Review and Meta-analysis. The Journal of American Medical Association Intern Med. Vol. 174. No.3. pp. 357-368.

Holzel, B.K., Carmody, J., Vangel, M., et al 2011, Mindfullness Practice Leads to Increases in Regional Brain Gray Matter Density, Journal Psychiatry, Vol. 191, no. 1, pp. 36-43.

John, S., Verma, S., Khanna, G 2011, The Effect of Mindfulness Meditation on HPA-Axis in PreCompetition Stress in Sports Performance of Elite Shooters, NJIRM, Vol. 2, No. 3.

Lutgendorf, S. \& Costanzo E 2003, Psychoneuroimmunology and Health Psychology: An integrative model, Brain, Behavior, and Immunity, Vol. 17, pp 225-232.

Malinowski, P 2013, Mechanisms Of Mindfulness. How Meditation Fosters Positive Psychological Change, Achtsamkeit, Ein buddhistisches

Mousavi, E., Esmaeili, A., \& Saless, S 2015, The Effect of Positive Thinking on Quality of Life and Resiliency of Cancer Patients, Razavi International Journal of Medicine. Vol. 3, No. 3.

Nurdin, A 2010, Pendekatan Psikoneuroimunologi, Majalah Kedokteran Andalas. No.2. Vol.34. JuliDesember 2010

Ott, M.J., Norris, R.L., Wu, S 2006, Mindfulness Meditation for Oncology Patients: A Discussion and Critical Review. Sage Journals, Vol. 5, no. 2, pp. 98108 
Shaheen, N., Andleeb, S., Ahmad, S., et al 2014, Effect of Optimism on Psychological Stress in Breast Cancer Woman. FWU Journal of Social Science, Vol. 8, no. 1, pp. 84-90.

Singer, S., Munshi, D., Brahler, E 2009, Prevalence of mental health conditions in cancer patients in acute care-a meta-analysis. Annals of Oncology. 10.1093/annonc/mdp515First published online: November 3.

Söllner W 2006, Psychotherapy Is The Basic Treatment, Dept. of Psychosomatic Medicine and Psychotherapy General Hospital Nuremberg, EACLPP.

Sridharan, D., Levitin J., Menon, V, 2008, A Critical Role For The Right Fronto-Insular Cortex In Switching Between Central-Executive And Default-
Mode Networks, Proceedings of the National Academy of Sciences of the United States of America, Vol. 105, No. 34, pp. 12569-12574.

Taren, A et.al 2015, Mindfulness Meditation Training Alters Stress-Related

Amygdala Resting State Functional Connectivity: a Randomized Controlled Trial, Social Cognitive and Affective Neuroscience, Vol.10, No. 12, pp. 17581768

Witek-Janusek, L., et al 2008, Effect of Mindfulness Based Stress Reduction on Immune Function, Quality of Life and Coping in Women Newly Diagnosed With Early Stage Breast Cancer. Brain, Behavior, and Immunity, Vol. 22, pp. 969-981. 